\title{
Stage life and stage death (after Veltruský)
}

\author{
Silvija Jestrović
}

\author{
Full fathom five thy father lies; \\ Of his bones are coral made; \\ Those are pearls that were his eyes: \\ Nothing of him that doth fade, \\ But doth suffer a sea-change \\ Into something rich and strange.
}

(Act I, Scene II The Tempest)

Ariel's famous song from Shakespeare's The Tempest offers a verbal image to describe the death of young Ferdinand's father. The image is one of metamorphosis - bones turn into coral, eyes become pearls, an unremarkable, mortal body turns "into something rich and strange." This is, however, no ordinary ashes-to-ashes-dust-to-dust death. Even though transformation of the live matter into a different form of energy cannot be denied to our everyday, mundane deaths, the "turning into something rich and strange" is not guaranteed. In Ariel's song, the transformation of mortal into immortal, of alive into lifeless, of the plain physical body into an object that resembles a jewel or at least a beautifully crafted death mask is a different kind of passing - it is a stage death. The verbal image performs the metamorphosis, the change is gradual and conjured in front of our eyes - death (as most of the other events on Prospero's island) is an illusion. Ferdinand's father, as we all know, will be found very soon alive and well, as Prospero's plotting of the shipwreck and Ariel's execution of the plot, play out to teach the treacherous Duke of Milan and his entourage a moral lesson. Yet with every utterance of Ariel's song the "sea-change," the transformation from body to object, unfolds again and again to remind us that stage deaths are provisional.

This transformation that Ariel's song depicts could be read as a poetic version of Juiri Veltruský's famous essay "Man and Object in the Theatre" (VELTRUSKÝ 2016 
[1964]: 147-154). ${ }^{1}$ He points out that the distinctive character of theatre is its ability to transform a lifeless object on stage into a performing subject, and to turn a live actor into a thing without will:

The function of each component in the individual situation (and in drama as a whole) is the result of the constant tension between activity and passivity in terms of the action, which manifests itself in a constant flow back and forth between the individual components, people and things. It is therefore impossible to draw a line between subject and object, since each component is potentially either. (VELTRUSKÝ 2016 [1964]: 90)

Veltruský starts with the premise that in reality the relationship between the animated and the lifeless is a stable one, whereas theatre has the potential to destabilise this relationship, creating a "dialectic antinomy" between the human body and the object on stage. The "sea-change" Shakespeare depicts as a poetic verbal image, is to some extent a depiction of the workings of stage semiotics. It sublimates how, in stage performance, things - bodies and objects - stand both for themselves and for other things. If The Tempest is a dramatization of theatre about theatre, then Ariel's song also talks about the effect of stage semiotics. But how does the "sea-change" get to be experienced? Shifting from the nouns to the adjectives rich and strange, to describe the beauty of something alive turning into something lifeless, the poem expands the semiotic territory into ambiguities of interpretation: what/ who is this new form, this rich and strange thing? And what does it mean? What does it tell us about death itself? Or at least what does it tell us about stage death? The uncertainty inherent in the word "something" together with the interpretative openness of the adjectives "rich" and "strange," involves another dimension that both encompasses and escapes our semiotic impulse. That is the elusive phenomenological terrain of reception, experience, affect, even metaphysics - the ever changeable and mysterious performativity of here and now of the utterance. The play, The Tempest, is often interpreted as theatrum mundi and as a play about theatre itself. It is a play about many other things too: about power and subjugation, about rightful and treacherous rulers, about the colonial conquest. This does not make The Tempest any less of a play about theatre though, especially given that theatre has - either intentionally or inadvertently - always been political. Hence, even the semiotics of the "sea change" - the alchemy of transforming something alive into something lifeless and vice versa - does not escape political and ethical dimensions. Before we look into more specific examples of this "sea change" - into the allusive space that the dialectic antinomy between a person and an object on stage opens - we should first determine where does this stage, this space of transformation, begin and end.

1 The most recent translation of the article is published, as "People and things in the theatre" (DROZD, KAČER and SPARLING 2016: 147-156). 


\section{Stage Parameters}

Veltruský writes about theatre, where actors and objects embody the script. For him the space of enhanced flexibility of signs - to the extent that objects can come to life and living beings can appear completely without will - is the theatrical stage. I argue that the "dialectic antinomy between body and object," alive and lifeless, does offer a broader conceptual framework that goes beyond the from-page-to-stage process and beyond dramatic theatre alone. So, rather than asking where does the stage begin and end, it might be more useful to ask, how does the stage extend?

Here are two definitions of theatre: one is by Veltruskýs fellow Prague Structuralist Jindřich Honzl; the other is by the performance artist Marina Abramović. Honzl, drawing from Czech aesthetician Otakar Zich, writes:

Everything that makes up reality on stage - the playwright's text, the actor's acting, the stage lighting - all these things in every case stand for other things. In other words, dramatic performance is a set of signs. (HONZL 1976: 76)

The specificity of the theatrical sign, notes Honzl, is in the potential of any stage vehicle to stand for any signified class of phenomena; thus, there are no fixed representational relations. This transformability of theatrical signs enables a free play with theatrical signifiers which is also at the core of Veltruskýs dialectic antinomy between person and object. Honzl describes the set used in Meyerhold's staging of The Death of Tarelkin, as a cylindrical construction that looks like a meat grinder: "It is only when we see the actor pacing back and forth in the cylindrical structure like a prisoner and clutching its slats like bars that we realize the function of this prop: it is a cell” (HONZL 1976: 78). Honzl uses this example to demonstrate that we know for certain what the props in a theatrical production signify only through the ways actors use them. By the same token, in a performance space, we do not know if something is alive or lifeless, an active subject or an object without will, untili it is utilised through perfromance -until it interacts (or fails to interact) with other elements in the space.

Performance artist Marina Abramović draws a sharp demarcation between theatre and performance along the lines of performance art's resistance to semiotization. In her 2010 interview for The Guardian, following her famous Artist is Present performance in MOMA, she offered her definition of performance versus theatre:

Theatre is fake: there is black box, you pay for the ticket you sit in the dark and you see somebody playing somebody else's life. The knife is not real, the blood is not real, and the emotions are not real. Performance is just the opposite: the knife is real, the blood is real, and the emotions are real. (The Guardian 2010)

The knife, or rather the razor blade in her performance Lips of Thomas, was indeed real. So was the blood that it drew. Lips of Thomas was first performed in a gallery in Innsbruck, Austria in 1975, it was then re-performed in 1993 and in 2005 respectively, 
both times in the Guggenheim Museum as part of the Seven Easy Pieces project. In this performance, that has elements of religious sacrifice, Abramović pushes her body to the limits. She eats a kilo of honey, drinks a litre of red wine, and flogs herself violently. As the performance progresses, her acts grow increasingly self-harming including the now iconic moment when she carves a star onto her belly with a razor blade. She then lays on a cross made of ice blocks, while a heater on the ceiling is aimed at her starshaped wound to make it bleed more. Even though the blood and the pain is real, Lips of Thomas is not without its theatricality. The artifice, which Abramović reduces to mere fakeness in her definition of theatre, emerges through the props, the symbols, the setting. Theatricality emerges as the performer plays with, displays, questions and destroys a handful of symbolic objects and she re-iterates acts that have been many times performed, theatricalized, and instrumentalised in art, ritual, and everyday life - the cross and the star, the religious ritual of self-sacrifice, and the symbolic meanings of wine and honey. Once framed within the performance space - or through the performer's own "charismatic space" (as in the film Artist is Present Abramović advices her surrogate performers, saying: "You have to find your own charismatic space.") - these elements start to act theatrically not only for what they are, but also as signs for something else. The visceral experience of pain - its ultimate performativity - unfolds in a setting and through a set of actions that inevitably produce their own semiotics, which is also theatrical despite the performer's best efforts to separate theatre semiotics from that of performance art.

Moreover, the signs - the cross and the red star - read differently within different temporal frameworks within which the piece was re-performed. At the time of its first performance in Innsbruck, Abramović was a little-known young artist from socialist Yugoslavia. The cross (sign of supressed religion) was a challenge to the bleeding red star - a critique of communism. The re-performance in 1993 took place amidst the blood-bath of the civil war in which socialist Yugoslavia was drowning. The body of the performer prostrated on the ice cross with the star shaped wound on her belly bleeding, colouring the shape of the wound in red, suddenly got different connotations. The tragedy of the religious and ethnic wars that marked the downfall of Yugoslavia could be read in the inscriptions of the suffering body on stage and in her acts of sacrifice. The religious symbolism is no longer the yearning for supressed spirituality and the critique of a rigid regime, but rather a critique of religion that the war mongering politics has instrumentalised. The final re-performance in 2003, was a major showcase of Abramović as a super star of the performance art world and yet another reading of Lips of Thomas emerged - more personal, autobiographical, as the red star and the partisan paraphernalia used as props began to relate to her partisan parents and her childhood. The form of the re-performance, somewhat antithetical to the claim of immediacy and ephemerality of performance art, could also be read as the artist's attempt to secure her legacy, a process of canonisation of her opus and that of other seminal performance art works that she has re-performed as part of this project. Semiotization - or in Honzl's terms "things standing for other things" - emerges here too, despite the authenticity of the blood and the pain. The semiotic process enhances the piece with 
layers of meaning, while also making evident the transformability of signs in different performance contexts. In other words, not even the knife/razor blade nor the real blood could stop the process of semiotization.

But what about those elements that do resist semiotization? What are the limits of semiotics of real blood and pain? Veltruskýs "Man and Object in Theatre" does not at any point blur the lines between stage and reality, if anything Veltruský, together with Honzl, Zich and others, points to the difference between the workings of theatrical signs from those in real life. Nevertheless, the instances when these lines are blurred, as in some performance art examples like Lips of Thomas, do not make Veltruskýs concept of dialectic antinomy between person and object obsolete, but rather more complicated. The final part of Lips of Thomas is a tableaux: Abramović lays on the cross made of ice. The status of the live body on stage changes from activity to passivity - in terms of willpower the difference between the body and the cross is marginal. The body of the performer with bleeding star carved onto her belly joins other symbolic objects utilised on stage to make the final poignant display. The slow, gradual change of the display comes from the energy transfer that the heater installed on the ceiling provides - the ice begins to melt, while the star shaped wound carved into Abramovićs belly bleeds more intensively. The live body, just like the lifeless cross made of ice, has no capacity for action. The intervention, however, comes from the audience crossing over into the performance space to rescue Abramović from bleeding to death, bringing the first performance of Lips of Thomas in Innsbruck to an abrupt end. The transformation from body to object, from alive to lifeless, has almost exhausted its semiotic potential. The immediate dilemma of where the performance ends, and what are the limits of looking on, takes over. This anecdote that opens many further questions about the role of audience, complicity, and participation, might, however, also be deployed for a counter argument to say that the theatrical transformability of signs stops once real blood is drawn, so theories of Veltruský, Honzl and others cannot really work in the context of performance art. I would like to propose a counter argument: that this example, including the audience's intervention, created an additional dialectical level to the concept of alive and lifeless in performance. The close proximity between stage death and real death added ontological and ethical dimensions to the performance semiotics. Moreover, in the subsequent performances of the Lips of Thomas at the Guggenheim Museum the audience, by then familiar with Abramović's work, did not intervene - the pain was expected, and the real blood became a performance convention. The "real" became subjected to the process of stage semiotics - the real knife and the real blood became performance conventions.

\section{Extending the limits of the stage: person and object in the city}

In her essay "Czech Performance Theory," Veronika Ambros has argued that conceptual frameworks of the Czech Structuralists such as those by Honzl, Veltruský, Burian and Mukařovský amount to a distinct performance theory, that has remained neglected 
in the field of Performance Studies. The concept of the dialectic antinomy between person and object, although conceived within the context of theatrical stage, is among those that offer hermeneutic possibilities that extend beyond theatre and into various liminal territories of performance. As soon as a performance space has been demarcated, be it as a traditional theatrical stage, in a gallery, or on the street, there is a possibility for Veltruskýs dialectic antinomy between alive and lifeless to take place. Whether knife is of sharp metal or bendy plastic, whether real blood is spilled or just ketchup smeared, as soon as performance space is demarcated in one way or another the signs enter the state of heightened transformability - alive can become lifeless and vice versa. Sometimes, in this relationship between person and object in a performance space there is a close philosophical proximity between alive and lifeless, both theatrical and ontological. At other times, there is even a physical proximity, to put it almost crudely, between stage death and an actual one - when the transformability of theatrical signs viscerally reminds us of its opposite - the rigidity of signs to move freely between alive and lifeless in real life. In my previous work, I have applied Veltruskýs concept beyond theatrical stage as a means to analyse two performances of the city. ${ }^{2}$ One was the performance of the cellist Vedran Smajlović on the ruins of National Library in Sarajevo during the siege of the city (1992-1995); the other was Antony Gormley's project Event Horizon (London 2008). I am revisiting these two case studies here with a more particular focus on body and object outside designated theatrical spaces to explore how limits of the stage become extended through the lens of this dialectic antinomy inherent in the semiotization process of performance.

The photo of the Sarajevo cellist wearing a black tuxedo, making the ruins of the National Library his stage is one of the most iconic images of the siege. This performance, at the same time, commemorated the killing of the city and staged an act of resistance to urbicide. I have argued that Smajlovićs performance is not only about re-humanising the devastated city and breathing life into the ruins, but also a more ambiguous and dialectical affair of turning flash into stone and stone into flash akin to Veltruský's concept of person and object. Everyday life in besieged Sarajevo unfolded theatrically, nearly resembling the body-object relationship that Veltruský ascribed to the theatrical stage. Violence itself often involves a similar kind of dialectic antinomy between living and lifeless, which, as Susan Sontag put it, "turns anybody subject to it into a thing" (SONTAG 2003: 11). Yet this dialectic antinomy emerges in Sarajevo in a more complex way. It manifests itself through the ambiguity between passivity and activity: the passivity of the vulnerable body becoming an object (a target for a sniper, for example) and the activity of the body in daily acts of survival. Indeed, the image of Smajlović playing music on the library ruins reveals a high degree of identification between person and space/object - between, as the title of Richard Sennatt's book (1994) has it "flesh and stone."

Gormley's 2008 project Event Horizon was an installation of 31 iron sculptures representing the human body displayed on streets and the rooftops of central London, 
significantly changing the familiar urban landscape. Gormley's cast-iron men brought an anthropomorphic element to city vistas, establishing a variety of "intertextual" links - from Renaissance sculptures of patron saints offering protection from the rooftops of public and private buildings, to the humanised angels standing on the edges of Berlin rooftops in Wim Wenders's iconic film Wings of Desire (1987). These angels of cast-iron prompt an array of metaphors and references to city-dwelling, security, and surveillance. The sculptures exhibit a dichotomy between the vulnerability of a bare body standing on the edge of a tall building and its iron cast material. By the same token, they place the city and its familiar tourist vistas in the context of a topical discourse of surveillance, especially in London's tense urban climate following the bombings of 7 July 2005 and the subsequent terrorist attacks.

Even though Smajlovićs performance took place in an extreme environment of violence and destruction, both his and Gormley's events were interventions into the everyday life of their cities, and both invoked the ambiguity between person and object/ architecture that Veltruský found immanent in the theatre. This dynamic relationship is established through Gormley's unpredictable placing of his iron-cast men - on the edges of buildings, as if they could jump or flip over at any given moment and turn stasis into mobility, or in a narrow pathway of Waterloo bridge so that passers-by had to manoeuvre their way around the sculpture and interact with it, sometimes touching it accidentally, at other times hugging it to pose for a photo. In Smajlović's performances on ruins and graveyards that often took place during severe shelling of the city, the performer in black tuxedo, playing his instrument as if he was in some elegant concert hall, made the war landscape strange. The performer's body emerged as an unpredictable and almost alien object amongst the ruins of the city. In Smajlović's performances, the ambiguity between living and lifeless was played out further: the live performances on the library ruins and in graveyards re-animated these spaces. In return, the ruins made the presence of the live performing body somewhat tentative. This foregrounded the void, the loss, the violence, so much so that the alive body almost became one with the lifeless ruins. Indeed more often than not, Smajlović played for the dead.

\section{From person to object and back: variations}

In the final part of this essay, I would like to briefly look at four variations based on Veltruský's antinomy between alive and lifeless that include both performances on theatrical stages and those in other spaces, foregrounding variously aesthetic, political and existential meanings. I will call these variations Basic Metamorphoses, Stage Birth, Uneasy Dichotomies, and Stage Death. These variations highlight both the semiotic usefulness of Veltruskýs concept and the philosophical challenge it postulates to the dynamics between alive and lifeless, activity and passivity, subject and object in both theatre and performance.

Basic Metamorphoses relate to Honzl and his example of the set for Mayerhold's performance of the Death of Teralkin mentioned earlier in this essay. There are, however, 
numerous further examples of a similar kind where the meaning of a theatrical sign is not apparent on its own, but becomes defined through physical stage action. For instance, in Robert Lepage's production The Far Side of the Moon (2000), an ironing board is used as an exercise machine in one scene and it becomes a car in another. In Théâtre de Complicité's production The Three Lives of Lucie Cabrol (1994), a broom used for sweeping the stage, turns into a horse. The actors in the same production are stage characters in one scene, while in another they turn into trees and bushes. These examples point to the relationship between mimetic and non-mimetic representation in theatre. In this context, the actor's body on stage too becomes a set of transformable signifiers.

Stage Births: Arguably, puppets are among the most illustrative example of stage births. Puppets foreground the dialectics and the paradox between alive and lifeless on stage. On the one hand, manipulated into coming to life, puppets have the capacity to perform the process of animating the lifeless more than any other body/ object on stage. On the other hand, even when puppets come to life, their essence as objects, their lifelessness, never entirely leaves them. To illustrate this claim, I choose Philip Glass's opera Satyagraha (first performed in 1980) and its spectacular 2008 staging by Phelim McDermott, with puppetry and production design by Improbable Theatre company, for the English National Opera. Satyagraha, meaning "truth force" is about early years of Mahatma Gandhi in South Africa as a young lawyer (between 1893 and 1914). Gandhi adopted the name Satyagraha for his nonviolent resistance movement, which was founded to fight discriminatory laws and practices deployed by the British Government on the Indian minorities in South Africa at the time. The opera production in question used live performers, choruses, video projections, and improvisational puppetry that turned objects into puppets to tell the story. Newspapers were prominently featured during the show as Gandhi was the editor of the newspaper Indian Opinion and used the print media frequently in his struggles for justice. Shaped by the artists of the Improbable Theatre, the newspaper as objects underwent a variety of transformations as they turned into stage figures in front of the audience's eyes. The newspaper were metamorphosed into giant, grotesque puppets. Both imposing and fragile, they represented the minorities in South Africa for whose rights Gandhi came to fight. The material object - the paper - connected the print media as the means through which some of the struggle was conducted and the social figures for whose rights Gandhi fought. Moreover, given that the libretto's structure was non-linear and with strong parallels to the Indian myth Bhagvad-Gita, the oversized puppets made of newspaper emerged as mythical warriors connecting various associative and symbolic levels of the piece. Hence, as Ambros points out in her essay "Prague's Experimental Stage: Laboratory of Theatre and Semiotics," the spectacle of this staging of Glass's opera "is not based on a tension between actor, character, and stage figure, but on the oscillation between static and dynamic, between the inorganic material and its animated appearance, between the mechanic and the anthropomorphic performance, and between fine arts (sculpture, painting) and performing arts" (AMBROS 2008: 56). In another essay "Puppets, Statues, Men, Objects and the Prague School," Ambros translates a passage from Zich that says: 
As much as marble is not a sculpture, only shaped marble is, in much the same way, only shaped actor is the character, with the difference that the actor himself accomplishes the shaping of the character, while being shaped himself. (ZICH in AMBROS 2012: 80)

This line could be continued further to describe stage births such as the shaping of the newspaper into puppets and the puppets into stage figures and characters. This stage birth is a complex metamorphosis from object (newspaper, etc.) into acting subject (Gandhi's supporters), as it requires a kind of symbiosis between live body and object. Ambros points out that more than twenty years after writing "Man and Object in Theatre," Veltruský added some further thoughts to the concept:

The fact remains that inanimate objects cannot act physically. They signify action only when that signification is bestowed on them by human beings; even a marionette cannot act unless its strings and wires are pulled by the puppeteer. (VELTRUSKÝ in AMBROS 2012: 83)

Veltrusky introduces the term vivification to refer to the phenomenon of an object giving the impression of life. The transformation of lifeless object into animated subject is the act of vivification - whereby life is needed to breathe life into an inanimate object - a phenomenon we have named staged birth.

Uneasy Dichotomies: The transformability of signs in performance, the possibility to turn subject into object and vice versa, has often problematized representation and been used as means of foregrounding critical issues. To illustrate this point, I will briefly examine the controversial installations of South African artist Brett Bailey entitled Exhibit $B$ that uses the format of human zoo to confront European audiences with their past of colonial violence and genocide. Exhibit $B$ is part of a series of installations that include Exhibit $A$ and Exhibit $C$ (forthcoming), which have toured from 2010 through the whole of Europe and in South Africa, igniting protests when staged in Berlin and London. ${ }^{3}$ The exhibit aimed to expose the root of racism flourishing in the $19^{\text {th }}$ century, marked by human zoo displays that toured major cities of the Western Europe. Sarah Baartman, the black woman known as the "Hottentot Venues" is one of many infamous examples of such colonial practices. She was displayed in her life time in various $19^{\text {th }}$ century theatres and halls, and upon her death, her body was dissected and exhibited again. Bailey's series is a catalogue of atrocities that were committed and concealed by European colonisers in Africa. He describes his project as:

a human installation that charts a river of racism running through European ethnographic displays and human zoos, and the scientific racism that spanned the later $19^{\text {th }}$ and early $20^{\text {th }}$ centuries, and the current policies towards African immigrants in Europe. (Brett Bailey, Third World Bunfight homepage)

3 The evocation of the "human zoo" format in Exhibit B provoked protests and heated discussions that even led to a withdrawal of the London show before its actual opening. 
The Exhibit B, uses the $19^{\text {th }}$ century freak shows as an inspiration to investigate into the uncomfortable truths of the European colonial past mapping the trajectories of $19^{\text {th }}$ century human zoo exhibits. On the homepage of Bailey's Third World Bunfight company, featuring the Exhibit B, it is stated in bolded letters: "This is an exhibit not a dramatic performance." The live bodies here are not performing, they are deliberately turned into objects for display. As one walks through the installation live bodies of the performers are displayed alongside sculptures, paintings and other artefacts. In one installation, a black performer represents a semi-nude Congolese woman, leather bond encircling her neck, as she gazes in the gilded mirror. Another entitled "The Brief History" features a figure representing a Kenyan man castrated during the Mau Mau uprising in the 1950s set among the bone china of an elegant English afternoon tea. Still another, features asylum seekers under the title "Found Objects" - a critical parodic gesture not only of the current reverberations of colonial legacies, but arguably, of some contemporary socially engaged art practices.

In his recent response to the refugee crisis, entitled Sanctuary, Bailey used a similar method of installation where various objects and spaces related to the refugee experience were displayed alongside the migrant figures. Staged in a form of a labyrinth of European migration, Sanctuary, like Exhibit B, confronts the viewer with her/his own conformity (and even complicity). The dialectical antinomy between body and object depicts the violence of colonial history and legacy. The body is not neutral (it has never been), but here it is especially marked through its skin colour, ethnicity and social abjection. The relationship between alive and lifeless is tense and disconcerting. The body is shown framed as a biopolitical object that nevertheless, haunts the colonizer's version of history. The fine English china and the suffering body of a black man both become objects on display, confronting different versions of colonial history and reality - that of the colonizer and of the colonized.

The dialectic antinomy between body and object does not only foreground the transformability of theatricalised signs, but also the way we look at them. In puppet theatre, Ambros writes, "there is not an $a$ that watches $b$ who is pretending to be $c$, typical of 'normal theatre' because in puppet theatre most of the time the positions of $b$ and $c$ merge" (AMBROS 2012: 56). In Exhibit B and Sanctuary the merging of $b$ and $c$ occurs through the performer's nonperforming ("this is an exhibit not a performance"). The line between the objectified figure that the performer represents and the self on display becomes blurred through the performer's own bodily markers that connect her to those she stands for in the exhibit. This merging of $b$ and $c$ creates the uneasy dichotomies of person and object in Bailey's work. Moreover, $a$ - the onlooker - does not remain safe and stable either. As theatre ciritic Lyn Gardener, reviewing the Exhibit B puts it, "the silent, unmoving figures at the centre of each one of the installations makes us confront how we look, where we look and what we are prepared to see" (GARDENER 2014).

The strategy Bailey uses is that of placing the live body on the same semantic level as an object in the display. The live body acquires a similar status to sculpture - in a process of rigidification to use Jakobson's term (AMBROS 2012: 83). The only differ- 
ence from the sculpture is that these figures sometimes return the gaze. In their brief, sudden gestures of returning the gaze, another shift between object and person occurs and another change between statics and dynamics - the semiotics of this shift is not only formal and theatrical, but deeply political. In any case, the strategy that is used here to confront the audience with their own passivity and colonial amnesia is indeed the one that Veltruský describes in "Man and Object," whereby a living being can be turned into an object void of will. The transformation of person into object is not only a semiotic process of theatre, it is also a process akin to that of colonial violence. In the dialectic antinomy between alive and lifeless, sometimes the sign is not just a sign.

Stage Death: this is a gestural metamorphosis, a sign of finality, but not the finality itself. To elaborate more on this assertion, I would like to take a brief look at an example were stage death and physical death are placed in close proximity. The case in point, is the performance The Church of Fear: I'm no longer afraid of the foreign in me by German theatre's enfant terrible Christoph Schlingensief, who died of cancer in 2010 at the age of fifty. This performance is centred around Schlingensief's cancer diagnosis. The live performance shifts between direct readings from Schlingensief's autobiographical writing to actors theatrically representing scenarios from that writing. The director appears as himself creating a tension between the actors reading the diary of a dying man and the actual stage presence of the dying man in question. Throughout the live performance, a film is projected onto three screens above and at both sides of the stage. At times, the projected footage is played simultaneously to the reading of extracts from the diaries. The performance opens with the projected footage of cells under a microscope. Later on, film footage of a decomposing hare is shown and as it is played at high-speed, the illusion is created of the dead hare moving on its own accord - as if the dead animal is in control of its own decomposition. From the inside of the hare's decomposing body, a figure of a dancer shapes into being though montage. As the dancer rises and performs what seems to be the depiction of a bird ascending to the skies, the new set is revealed on stage, which most closely resembles the space of a Roman Catholic church. The dialectic antinomy between alive and lifeless becomes enhanced not only with new semiotic possibilities of film editing, but also through dichotomies of life and death - the live cancer cells that are deadly and the life dancing and flying out of the carcass. Schlingensief has described the performance as a "requiem mass" for the "future dead."

Even though his death was imminent, on stage at least it was always marked, but never entirely fulfilled. During the show, in theatre, death was just a sign, a semiotic process, despite the apparent interplay between reality of terminally ill Schlingensief on stage and artifice of the heightened stylisation of the piece. This is the paradox of the dialectic antinomy between alive and lifeless. Indeed the show is full of visual and performative layers that signify illness, death and decay as a transformation from alive to lifeless, but also its reversal - for instance, in the surreal video when a dancer emerges out of the hare's carcass. Schlingensief's Church of Fear was a means of coming to terms with his own illness and untimely, but imminent death. It was in a sense a rehearsal of one's own death, an exercise in coming to terms with mortality. Still, 
being a rehearsal, the possibility of repetition of enacting one's own dying over and over again, almost kept the finality of the physical death at bay. Hence, the Church of Fear was a death-defying performance about actual dying.

Speaking of real and stage deaths, an exquisite and much-beloved Serbian actor, Nebojša Glogovac, died in 2018, prematurely like Schlingensief. Glogovac was a brilliant Hamlet and a one of kind talent. He also acted in an adaptation of Ovid's Metamorphoses that premiered in 2010, in the Yugoslav Drama Theatre in Belgrade. As expressions of grief poured into social media, one post stood out. It was by the dramaturge of the Metamrphoses, Jelena Mijović, who also adapted Ovid's text for the Yugoslav Drama Theatre staging (directed by Aleksandar Popovski). She simply qouted the actor's lines from the play: "A tree to become, in an oak tree to turn..." The quotation evoked a complex kind of transformability - it referred to theatrical semiotization whereby an actor could turn into a tree, while the actual death of the actor, Glogovac, got equated with a stage metamorphosis. This poetic equation had also a strangly comforting note as a journey from life to death on stage most often came with a reaturn ticket. Like every stage metapmorphosis, stage death offers a possibility of return and repetition - the possibility to exercsie the dialectic antynom between alive and lifless over and over again. Hence in the death of this actor a kind of crossover between reality and thetare took place in the dramaturge's attempt to replace the finality of the real death, with the playfulness of a stage metamorphosis. In the crossover between the two, the banality of the actual death might still be transformed into something akin to "a sea change" from Ariel's poem that turned the mortal body into something "rich and strange."

In conclusion, Veltruskýs "dialectic antynomy of alive and lifeless" in theatre points to the double nature of stage metamorphosis - it is on the one hand, a semiotic process, while on another, it is an opening of an existential dimension that cannot be fully semiotised. This second aspect is formulated in the final lines of the afore mentioned adaptation of Ovid's Metamorphoses with which I like to end my reflection on stage life and death via Veltrusky's dialectic antinomy:

That was the time when unrequated love could turn into a flower, a wish could transform into a bird, and when desire could become rain... The time of the metamorphosis. Gods are scarcely with us these days and we keep avoiding them too. Only this is not entierly true. For it is not up to us. Life itself is a metamorphosis, and human beings but mere forms of it and subject to change. (MIJOVIĆ 2010) ${ }^{4}$

The stage metamorphosis through which an actor tunrs into a tree, where bodies become "something rich and strange," where live performers play close to death as Abramović, Smajlović and Schlingensief did, where puppets come to life, where bodies 
become sculptural objects exibiting the catalogue of colonial attrocities, and iron cast men on London rooftopes are about to leap into life - all involve a specific form of thetaricality (wether or not it takes place in theatre or on some other kind of stage). This theatricality, sublimated in Veltruskýs notion of dialectic antinomy between alive and lifeless, is as much about the imaginative possibility of one becoming the other (and reverting back) as it is about the actual realisation of the metamorphic potential.

\section{Bibliography}

AMBROS, Veronika. 1999. Czech Performance Theory. In Domenico Pietropaolo (ed.). The performance text. New York and Ottawa: Legas, 1999: 113-125.

AMBROS, Veronika. 2008. Prague's experimental stage: laboratory of theatre and semiotics. Semiotica 168 (2008): 45-65.

AMBROS, Veronika. 2012. Puppets, statues, men, objects and the Prague School. Theatralia (special issue on structuralist theatre theory) 15 (2012): 2: 74-88.

BAILEY, Brett. Third World Bunfight. Available online at http://www.thirdworldbunfight.co.za/ productions/exhibit-a-b-and-c.html.

DROZD, David, Tomáš KAČER and Don SPARLING (eds.). 2016. Theatre theory reader: Prague School writings. Prague: Karolinum Press, 2016.

GARDNER, Lyn. 2014. Exhibit B: facing the appalling reality of Europe's colonial past. The Guardian (12. 8. 2014). Available online at: https://www.theguardian.com/stage/2014/ aug/12/exhibit-b-edinburgh-festival-2014-review.

HONZL, Jindřich. 1976. Dynamics of sign in the theater. In Ladislav Matejka and Irwin R. Titunik (eds.). Semiotics of art: Prague School contributions. Cambridge, Mass.: MIT Press, 1976: 75-94.

JESTROVIĆ, Silvija. 2009. Anthropomorphic city horizon: structuralist's foregrounding in Antony Gormley's sculptures. In Veronika Ambros (ed.). Structuralism(s) today. New York/Ottawa: Legas, 2009: 191-203.

JESTROVIĆ, Silvija. 2013. Sarajevo: the world city under siege. In Kim Solga and D. J. Hopkins (eds.). Performance and the Global City. Basingstoke: Palgrave, 2013: 202-223.

MIJOVIĆ, Jelena. 2010. Metamorphoses (after Ovid). Yugoslav Drama Theatre/ Unpublished script.

O'HAGAB, Sean. 2010. Interview: Marina Abramović. The Guardian (10. 10. 2010).

Available online at: https://www.theguardian.com/artanddesign/2010/oct/03/interview-marina-abramovic-performance-artist.

SONTAG, Susan. 2003. Regarding the pain of others. London: Penguin, 2003.

VELTRUSKÝ, Jiří. 1964. Man and Object in the Theatre. In Paul Garvin (ed.). A Prague School Reader on esthetics, literary structure and style. Washington: Georgetown UP, 1964: 83-91. 